\title{
Víctor Infantes
}

Lyra mixta. Silva ejemplar de artificios gráfico-literarios

Madrid, Turpin Editores, 2015, 477 p.

ISBN 978-8494268243

\section{Ana Isabel Martín Puya}

Universidad de Córdoba

anaisabel.martinpuya@gmail.com

Desde el más remoto sistema de comunicación, el pictograma, la plasmación y transferencia de sentido se establece mediante la dotación de significado de una imagen vinculada a la realidad. Cuando la configuración de los códigos escriturales permita la comunicación mediante sistemas arbitrarios, imagen y palabra continuarán estableciendo estrechas relaciones en la búsqueda de una complementariedad significativa, cuya más relevante codificación probablemente se halle en la literatura emblemática. De esta, de su nacimiento y consolidación, de sus precedentes y de sus postrimeras manifestaciones, incluyendo obras situadas en sus márgenes, nos habla principalmente el presente volumen, producto de la labor concienzuda, exhaustiva y experta de un investigador apasionado por el tema y prestigiado justamente por su impecable desempeño. Desde la aparición de la obra de Alciato, fruto de unas decisiones autoriales y editoriales, hasta la poesía «visual» $\mathrm{y}$ «experimental» de las vanguardias del siglo xx, Infantes recupera en Lyra mixta. Silva ejemplar de artificios gráfico-literarios trabajos que atienden a las históricas relaciones entre texto e imagen a partir del nacimiento de la imprenta. Los 28 trabajos recogidos en este volumen (aparecidos entre 1980 y 2011) abordan el topos que los agrupa desde la teorización e historización de una trayectoria, el estudio bio-bibliográfico de determinados autores u obras características de un tiempo y unos procesos editoriales que establecen y determinan la interactuación entre figuraciones gráficas y textos, hasta la recuperación y edición de laberintos, jeroglíficos, tableros de juegos, carteles, poesía "gráfica», tablas de epactas. 
Infantes nos invita a sumergirnos en una de sus pasiones a través de una «(in) necesaria» pero atractiva «justificación» donde nos traslada el relato bibliográfico de su despertar a la fascinación por la interacción entre escritura e imagen. Como excelente pórtico de la compilación se revela, sin embargo, el primero de los trabajos recogidos («La textura del poema: disposición gráfica y voluntad creadora»), donde se ofrece "una rápida visión de la historia de unos géneros poéticos que han gozado en muchas ocasiones del fervor popular y constituyen la cara oculta, el contrapunto lúdico e ingenioso de las corrientes poéticas al uso» (13), lo que hace, a su vez, reivindicando el estudio de esta tipología de obras y composiciones situadas al margen de la norma y el canon. Recoge aquí el autor una clasificación de géneros reconocibles por la complejidad tanto formal como de su disposición gráfica, distinguiendo: acrósticos y retrógrados; aquellas en que, teniendo una disposición gráfica previa, no siempre queda esta resaltada; la poesía "visual" en sentido estricto: laberintos, pentacrósticos, pentacrósticos figurados y caligramas" (8-9), y la literatura emblemática y los jeroglíficos, en que se superponen otros códigos (plástico, espacial) al poético. De este modo, la conceptualización y el repaso (reivindicativo) por la tipología ofrecida en este primer trabajo nos introduce en el universo de las relaciones gráfico-textuales de unos géneros que en buena medida serán abordados más específicamente y a través de numerosos ejemplos en el resto del volumen.

Este trabajo y el tercero, «La poesía experimental antes de la poesía experimental», que nos lleva desde una reflexión sobre la «poesía visual y experimental» de las vanguardias hasta la ubicación de los precedentes experimentales de la literatura anterior y recoge una clasificación de géneros (de ingenio) gráfico-poemáticos, pueden servir como estudios introductorios para el neófito y curioso lector, pues en ellos se describe una tipología de esfuerzos del ingenio literario» (46) de una literatura no oficial (acompañados de ejemplos recogidos al final del capítulo): acrósticos, anagramas, poemas polilingües, centones, emblemas, divisas, literatura de enigmas, composiciones figuradas, etc.

La difusión de esta otra literatura marginal (o marginada en [por] la historia oficial) debe mucho a la sociedad y cultura barrocas, a su universo simbólico, celebrativo y excesivamente ornamental, a la incardinación y confluencia de códigos artísticos (de la arquitectura, escultura, pintura, literatura...) divergentes en sus ritos y celebraciones, que posteriormente dejaron sus huellas y condicionaron las impresiones derivadas de ellas, las relaciones de exequias, los himnos, las publicaciones de justas, honras, certámenes... En especial las obras litúrgicas y morales se vieron influenciadas por la vida barroca. Un ejemplo de la convivencia de esta literatura marginada o periférica con la literatura que conformaría el canon lo encontramos en el estudio dedicado a las incursiones de Calderón en justas y honras, y en el territorio de la literatura jeroglífica (trabajo 4), donde se prueba la participación de los grandes autores de estos juegos de ingenio figurativos en vinculación con el carácter celebrativo y teatral de la vida social barroca. Asimismo, el análisis propicia un repaso de la irrupción de los jeroglíficos en la 
literatura áurea, concluyendo con el análisis del jeroglífico que dedicó a Felipe $\mathrm{V}$ tras su muerte. Muy relacionado con éste, en el trabajo 5 se profundiza sobre la confluencia de danzas de la muerte (con Holbein como modelo en el sentir renacentista) y literatura jeroglífica desde finales del siglo XVI (aspecto relacionado con la publicación de honras, justas y relaciones de exequias) en obras que pueden o no incluir los grabados (limitándose en este caso la presencia de la imagen a su descripción y la reproducción textual de los jeroglíficos).

Entre los trabajos cuya lectura nos ha resultado más gratificante se encuentra el artículo sobre las danzas de la muerte de Holbein, donde Infantes describe las obras en que aparecen sus grabados para situarlas en una línea directamente vinculada con la tradición emblemática y con las decisiones editoriales que propiciaron el nacimiento del género. La minuciosidad y sencillez explicativa del investigador delinean un claro marco circunstancial de la formación de este tipo de obras (y el decisivo papel de editores e impresores en su configuración), a partir de obras tan relevantes y de tan grande fortuna y repercusión en Europa como las danzas y el alfabeto de la muerte de Holbein (1538), y los emblemas de Alciato (1531), y cuya más temprana influencia en España podría cifrarse en la traducción parcial del Emblematum Libellum y una posible traducción de Les simulachres \& historiees faces de la mort, ambas por Hernando de Villarreal (en 1557 y 1546 , respectivamente).

Alciato vuelve a tener un papel privilegiado en «Promesa para una hipótesis muy provisional de la secuencia emblemática» (cuyo título apunta ya a la indagación en el mundo de la emblemática desde el alcance de una elevada erudición sobre el tema), donde Infantes reflexiona sobre la «formación» y el «desarrollo gráfico/conceptual» del género, guiándonos a través de la historia de su disposición tipográfica en la página impresa y su constitución como volumen unitario compuesto a su vez de unidades independientes, y a través de las traducciones europeas de Alciato y obras continuadoras del modelo.

En dos ocasiones nos aproxima Infantes al universo bibliográfico del Format-Büchlein (Graz, 1670-1677), en sendos trabajos que se revelan complementarios (y fruto de la profundización en una misma línea). El primero de ellos es un acercamiento y reproducción de una ilustración, "poema metatipográfico» de Georg Wolffger, donde se «representa el microcosmos de un taller, sin olvidar el mensaje moral inscrito en las iniciales católicas y en la cartela colgada, y se configura, acudiendo al sincretismo más elemental de los propios elementos de la edición (letras, líneas, adornos, etc.) como una macla metatipográfica donde se manufactura el propio acto de imprimir» (318). El segundo constituye un análisis de este «primer tratado autónomo sobre las características técnicas y profesionales del arte de imprimir» (376), en que conviven la exposición textual y las representaciones gráficas.

Buena parte de los trabajos incluidos son ediciones y acercamientos a joyas icónico-textuales: muestras del gusto del investigador por el descubrimiento y divulgación de la obra artística que confiere a la imagen un sentido, nos des- 
cubren la incursión de un imaginario simbólico representativo de un ideario filosófico en el ámbito de lo lúdico, a través de la presentación de diversos tableros, plenos de imágenes y significados, convertidos en tradición, como el del juego de la oca, o el carácter también lúdico de un itinerario moral inscrito en un pliego cuyos pliegues y despliegues sucesivos marcan la trayectoria (icónica y textual) de la Navegación para el Cielo.

La diversificación de los objetos de estudio perfila un completo panorama de las interacciones imago-verba, donde los acercamientos de carácter teórico y estudios diacrónicos se ven complementados por análisis y reproducciones de algunas obras y figuras centrales del género emblemático y sus márgenes (Alciato, Hernando de Villarreal, Holbein), y de otras de carácter periférico pero representativas de unas dinámicas editoriales y actitudes autoriales concretas (Julio Fontana; Juan González de la Torre y su Diálogo de Nuncio Legato Mortal; Cristóbal Pérez de Herrera y los enigmas de sus Proverbios morales, y un largo etcétera).

Aunque la vinculación de lo artificial que conjuga imagen y escritura con el ingenio barroco se delimita en el predominio de unos objetos de estudio datados en el XVII, Infantes nos invita a un viaje por obras relacionadas con esta tradición nacidas entre el siglo XVI y el XIX (con sus rarezas excepcionales), ofreciéndonos una visión panorámica del conjunto a través de estas muestras ejemplares de una prolífica trayectoria, en esta agradecida compilación, atractiva en su variedad, y tanto a través del lenguaje preciso y certero de Infantes como de las numerosas reproducciones, para el curioso lector y para el estudioso que se sumerja en sus páginas en pos del conocimiento del autor. 